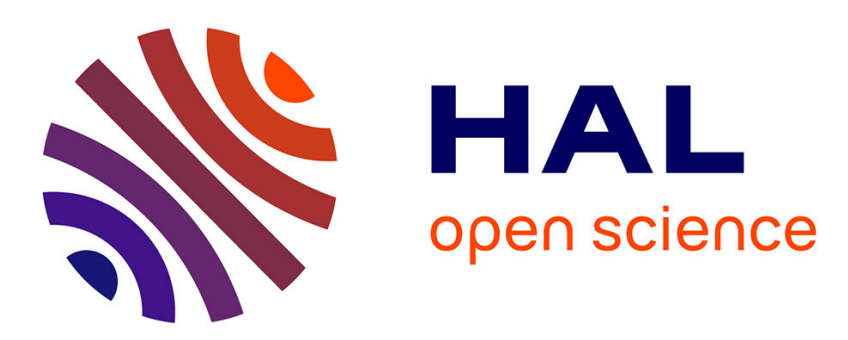

\title{
Enzymatic resolution of 1,1-dimethoxybut-3-en-2-ol and 1,1-dimethoxypent-4-en-2-ol, alpha-hydroxyaldehyde precursors for aldol-type reactions
}

\author{
R. Chenevert, S. Gravil, Jean Bolte
}

\section{- To cite this version:}

R. Chenevert, S. Gravil, Jean Bolte. Enzymatic resolution of 1,1-dimethoxybut-3-en-2-ol and 1,1dimethoxypent-4-en-2-ol, alpha-hydroxyaldehyde precursors for aldol-type reactions. Tetrahedron: Asymmetry, 2005, pp.2081-2086. 10.1016/j.tetasy.2005.05.013 . hal-00125718

\author{
HAL Id: hal-00125718 \\ https://hal.science/hal-00125718
}

Submitted on 2 Mar 2007

HAL is a multi-disciplinary open access archive for the deposit and dissemination of scientific research documents, whether they are published or not. The documents may come from teaching and research institutions in France or abroad, or from public or private research centers.
L'archive ouverte pluridisciplinaire HAL, est destinée au dépôt et à la diffusion de documents scientifiques de niveau recherche, publiés ou non, émanant des établissements d'enseignement et de recherche français ou étrangers, des laboratoires publics ou privés. 


\title{
Enzymatic resolution of 1,1-dimethoxybut-3-en-2-ol and 1,1-dimethoxypent-4-en-2-ol, $\alpha$-hydroxyaldehyde precursors for aldol-type reactions
}

\author{
Robert Chênevert, ${ }^{\mathrm{a}, *}$ Sébastien Gravil ${ }^{\mathrm{a}, \mathrm{b}}$ and Jean Bolte ${ }^{\mathrm{b}}$ \\ a Département de Chimie, CREFSIP, Faculté des Sciences et de Génie, Université Laval, Québec (Qc), Canada G1K 7 P4 \\ ${ }^{\mathrm{b}}$ Laboratoire de Synthèse et Étude de Systèmes à Intérêt Biologique, UMR 6504 du CNRS, Université Blaise-Pascal, \\ 63177 Aubière Cedex, France
}

Received 1 February 2005; revised 22 March 2005; accepted 6 May 2005

\begin{abstract}
Hydroxyacetals $\mathbf{2}$ and $\mathbf{3}$ were resolved by acylation with vinyl acetate in the presence of lipases in organic media. The reverse reaction, the enzymatic hydrolysis of the corresponding acetates, was also highly stereoselective and provided the opposite enantiomers.
\end{abstract}

\section{Introduction}

The development of methods for stereoselective carboncarbon bond formation using aldol-type reactions is a major focus of interest in organic synthesis. ${ }^{1}$ Both chemical $^{2-5}$ and enzymatic ${ }^{5-8}$ aldol reactions with very high levels of asymmetric induction have been reported. Aldolases catalyze the reversible stereoselective addition of an active methylene donor (dihydroxyacetone phosphate or DHAP, glycine, pyruvate, etc.) with an aldehyde acceptor. To date, DHAP-dependent aldolases are the most widely used aldolases in organic synthesis. ${ }^{8}$ Transketolase catalyzes the condensation of a hydroxyacetyl group provided by decarboxylation of hydroxypyruvic acid with $\alpha$-hydroxyaldehydes to yield ketoses of $(2 S, 3 R)$-configuration. ${ }^{6}$ Lerner and Barbas et al. have shown that it is possible to obtain catalytic antibodies that catalyze stereoselective aldol reactions. ${ }^{5,9}$ Asymmetric aldol reactions catalyzed by metal-free organocatalysts, such as proline, have received increased attention recently. ${ }^{2,10-12}$ Chiral $\alpha$-substituted aldehydes are valuable substrates for Mannich, aldol, and related $\mathrm{C}-\mathrm{C}$ bond-forming reactions. ${ }^{13}$ Herein, we report the enzymatic resolution of 1,1-dimethoxybut-3-en-2-ol and 1,1-dimethoxypent-4-en-2-ol. ${ }^{14}$ These highly functionalized compounds are easily transformed into alde-

\footnotetext{
* Corresponding author. Tel.: +1 418656 3283; fax: +1 418656 7916; e-mail: robert.chenevert@chm.ulaval.ca
}

hydes by hydrolysis of the acetal group or ozonolysis of the double bond.

\section{Results and discussion}

\subsection{Substrate preparation}

Hydroxyacetal $\mathbf{2}$ and $\mathbf{3}$ (Scheme 1) are readily available by the addition of a Grignard reagent to dimethoxyacetaldehyde $\mathbf{1}$ (glyoxal dimethyl acetal). This compound is commercially available but undergoes oligomerization and we found it more convenient to prepare it by a two-step method: first treatment of furan with bromine

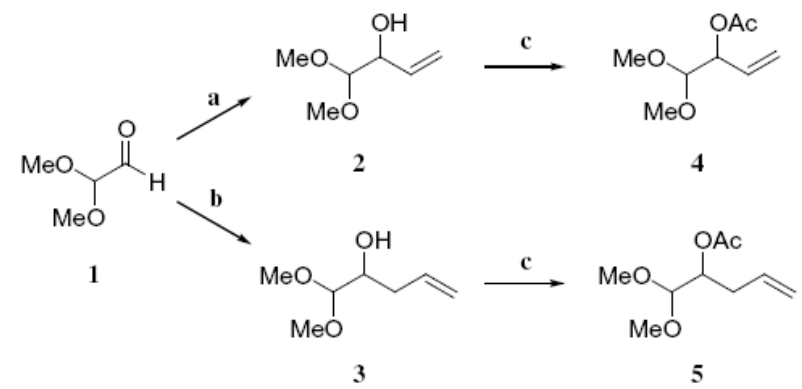

Scheme 1. Reagents: (a) $\mathrm{CH}_{2}=\mathrm{CH}-\mathrm{MgBr}$, THF; (b) $\mathrm{CH}_{2}=\mathrm{CH}-\mathrm{CH}_{2}-$ $\mathrm{Br}$, In, $\mathrm{H}_{2} \mathrm{O}$ or $\mathrm{CH}_{2}=\mathrm{CH}-\mathrm{CH}_{2}-\mathrm{MgBr}$, THF; (c) $\mathrm{Ac}_{2} \mathrm{O}$, DMAP, pyridine. 


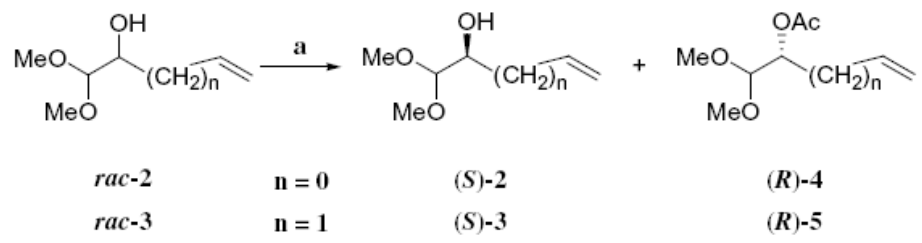

Scheme 2. Reagents: (a) vinyl acetate, enzyme.

in methanol ${ }^{15}$ followed by ozonolysis of the double bond. Grignard addition of vinyl magnesium bromide on $\mathbf{1}$ in THF provided $\mathbf{2}$ in moderate yield (both reagents are freshly prepared for best yield). Compound $\mathbf{1}$ was treated with allyl bromide and indium powder in water (Barbier reaction) to give homoallylic alcohol 3. Indium metal is expensive and on preparative scale, 3 was prepared by Grignard reaction of allyl magnesium bromide with 1 in THF. ${ }^{16}$ The corresponding acetates 4 and 5 were prepared via the acetylation of $\mathbf{2}$ and $\mathbf{3}$ with acetic anhydride in pyridine in the presence of dimethylaminopyridine (DMAP).

\subsection{Enzymatic kinetic resolutions}

We examined both the acylation (transesterification) of alcohols $\mathbf{2}$ and $\mathbf{3}$ (Scheme 2) and the hydrolysis of esters 4 and 5 (Scheme 3) in the presence of commercially available lipases under various conditions. The reactions were monitored by gas chromatography on a chiral phase column allowing the simultaneous determination of conversion (c) and enantiomeric excesses (ee) of both product and remaining substrate. The results of the lipase-catalyzed acylation of substrates $\mathbf{2}$ and $\mathbf{3}$ using vinyl acetate as acyl donor and solvent are summarized in Table 1. Candida antarctica lipase B (CAL-B) not only showed the best performance in the analytical runs, but also gave excellent results for the acylation of $\mathbf{2}$ on a preparative scale (entry 1). In the case of alcohol 3, all of the active lipases ${ }^{17}$ showed good enantioselectivity ( $E$ $\geqslant 29$ ); among them Pseudomonas fluorescens lipase (PFL) gave the best enantiomeric excesses and therefore the highest $E$ value (entry 5).

In general, the transesterification of racemic alcohols and the hydrolysis of the corresponding racemic esters are complementary and lead to opposite enantiomers of both alcohol and ester. The results of the enzymatic hydrolysis of acetates $\mathbf{4}$ and $\mathbf{5}$ in a phosphate buffer at pH 7 are shown in Table 2. Among the lipases tested for the hydrolysis of racemic 4, CAL-B retained the high enantioselectivity already observed in the acylation reaction but lipase from Pseudomonas sp. also showed high enantiodiscrimination. Both lipases from Pseudomonas cepacia and lipoprotein lipase (LPL) displayed high enantioselectivity toward racemic $\mathbf{5}$. In regard to the ee of the product and the remaining substrate as well as the rate of conversion $(50 \%$ in $10 \mathrm{~h})$, LPL was the enzyme of choice for the resolution on preparative scale.

\subsection{Determination of absolute configurations}

The absolute configurations of $\mathbf{2}$ and $\mathbf{3}$ were determined by correlation with 1,2-diols $\mathbf{6}$ and 7 of known absolute configurations (Scheme 4). Thus, hydrolysis of the acetal function in acetonitrile/water in the presence of lithium

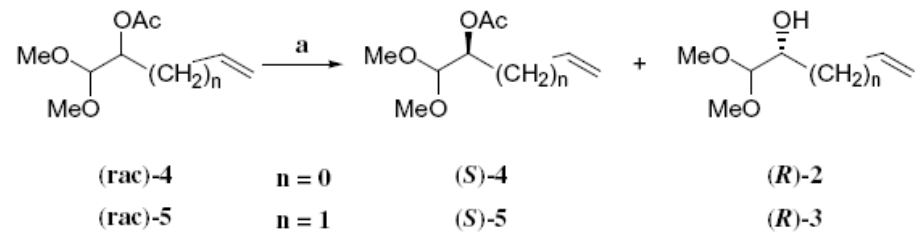

Scheme 3. Reagents: (a) phosphate buffer, pH 7.0, enzyme.

Table 1. Enzymatic resolution of $\mathbf{2}$ and $\mathbf{3}$ using various lipases under esterification conditions

\begin{tabular}{|c|c|c|c|c|c|c|c|}
\hline \multirow[t]{2}{*}{ Entry } & \multirow[t]{2}{*}{ Substrate } & \multirow[t]{2}{*}{ Enzyme $^{a}$} & \multirow[t]{2}{*}{ Time } & \multicolumn{2}{|c|}{ ee $(\%)^{b}$} & \multirow[t]{2}{*}{$c(\%)^{\mathrm{b}}$} & \multirow[t]{2}{*}{$E$ value } \\
\hline & & & & Alcohol & Acetate & & \\
\hline 1 & 2 & CAL-B & $36 \mathrm{~h}$ & 93 & 95 & 50 & $>100$ \\
\hline 2 & 2 & PSL & $14 \mathrm{~h}$ & 88 & 71 & 55 & 16 \\
\hline 3 & 2 & PCL & $3 \mathrm{~d}$ & 49 & 71 & 41 & 9.5 \\
\hline 4 & 2 & PFL & $3 \mathrm{~d}$ & 38 & 73 & 34 & 9.2 \\
\hline 5 & 3 & PFL & $24 \mathrm{~h}$ & 92 & 94 & 50 & $>100$ \\
\hline 6 & 3 & PCL & $20 \mathrm{~h}$ & 87 & 91 & 49 & 60 \\
\hline 7 & 3 & CAL-B & $3 \mathrm{~d}$ & 54 & 91 & 37 & 36 \\
\hline 8 & 3 & PSL & $3 \mathrm{~d}$ & 99 & 62 & 62 & 29 \\
\hline
\end{tabular}

${ }^{\mathrm{a}}$ CAL-B (C. antarctica lipase B), PSL (Pseudomonas sp. lipase), PCL ( $P$. cepacia lipase), PFL (P. fluorescens lipase).

${ }^{\mathrm{b}}$ Conversion $c$ and ee for alcohol and acetate, determined by chiral GC. 
Table 2. Enzymatic resolution of $\mathbf{4}$ and $\mathbf{5}$ using various lipases under hydrolysis conditions

\begin{tabular}{|c|c|c|c|c|c|c|c|}
\hline \multirow[t]{2}{*}{ Entry } & \multirow[t]{2}{*}{ Substrate } & \multirow[t]{2}{*}{ Enzyme $^{\mathrm{a}}$} & \multirow[t]{2}{*}{ Time } & \multicolumn{2}{|c|}{ ee $(\%)^{b}$} & \multirow[t]{2}{*}{$c(\%)^{\mathrm{b}}$} & \multirow[t]{2}{*}{$E$ value } \\
\hline & & & & Alcohol & Acetate & & \\
\hline 1 & 4 & CAL-B & $30 \mathrm{~h}$ & 94 & 92 & 50 & $>100$ \\
\hline 2 & 4 & PSL & $5 \mathrm{~h}$ & $>99$ & 78 & 44 & $>100$ \\
\hline 3 & 4 & LPL & $1 \mathrm{~d}$ & 78 & 26 & 25 & 10 \\
\hline 4 & 4 & $\mathrm{CE}$ & $1 \mathrm{~d}$ & 55 & 31 & 36 & 4.6 \\
\hline 5 & 4 & PLE & $1 \mathrm{~h}$ & 38 & 40 & 51 & 3.2 \\
\hline 6 & 5 & LPL & $10 \mathrm{~h}$ & 98 & 96 & 50 & $>100$ \\
\hline 7 & 5 & PCL & $3 \mathrm{~d}$ & 91 & 89 & 49 & 63 \\
\hline 8 & 5 & PLE & $10 \mathrm{~m}$ & 72 & 85 & 54 & 16 \\
\hline 9 & 5 & PFL & $3 \mathrm{~d}$ & 66 & 53 & 45 & 8.2 \\
\hline 10 & 5 & $\mathrm{CE}$ & $1 \mathrm{~d}$ & 63 & 54 & 46 & 7.5 \\
\hline
\end{tabular}

${ }^{a}$ CAL-B (C. antarctica lipase B), PSL (Pseudomonas sp. lipase), LPL (lipoprotein lipase), CE (cholesterol esterase), PLE (porcine liver esterase), PCL (P. cepacia lipase), PFL (P. fluorescens lipase).

${ }^{\mathrm{b}}$ Conversion $c$ and ee for alcohol and acetate, determined by chiral GC.

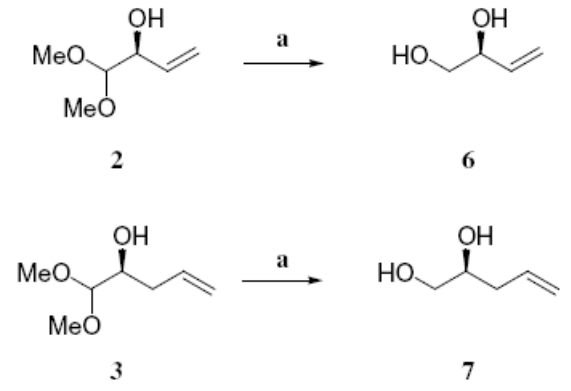

Scheme 4. Reagents: (a) (i) $\mathrm{LiBF}_{4}, \mathrm{CH}_{3} \mathrm{CN} / \mathrm{H}_{2} \mathrm{O}$; (ii) $\mathrm{NaBH}_{4}, \mathrm{H}_{2} \mathrm{O}$.

tetrafluoroborate ${ }^{18}$ followed by reduction of the intermediate aldehyde by $\mathrm{NaBH}_{4}$ in water in a one-pot procedure yielded the corresponding diols 6 and 7. In both the transesterification and hydrolysis reactions, the $(R)$ compound was the fast reacting enantiomer yielding the $(R)$-product and leaving the $(S)$-compound unreacted in enantiomerically pure form.

The configuration assignment confirmed that the catalytic preference of the lipases is in accordance with empirical models ${ }^{19,20}$ (Fig. 1). These models imply that the enantiodiscrimination of secondary alcohols by lipases is dominated by steric interactions. It is interesting to note that the Mosher's method using NMR analysis of MTPA ( $\alpha$-methoxy- $\alpha$-(trifluoromethyl)phenylacetic acid) ester of $\mathbf{2}$ produced the correct assignment of the absolute configuration. ${ }^{21-23}$

Finally, to show the usefulness of the title compounds we used compound $\mathbf{2}$ in an enzymatic aldol reaction catalyzed by transketolase (TK) (Scheme 5). Although TK is an enantioselective enzyme, which only accepts $\alpha$ hydroxyaldehydes with an $(R)$-configuration, it is more convenient to run the reaction with optically pure substrates instead of racemates in order to avoid enzyme inhibition by the $S$ isomer and to facilitate the purification procedure. ${ }^{24}$ The aldehyde substrate was prepared by ozonolysis and reductive workup with dimethyl sulfide, and used directly in the biotransformation. The reaction of the aldehyde with lithium hydroxypyruvate in the presence of transketolase and the required cofac-



A



B

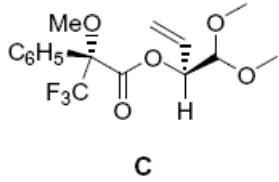

C
Figure 1. (A) Kazlauskas' model; M: medium substituent; L: large substituent. (B) (R)-2 corresponding to the model. (C) Mosher's ester of 2 .

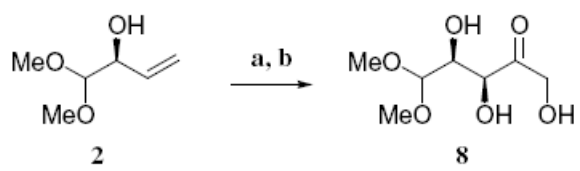

Scheme 5. Reagents and conditions: (a) (i) $\mathrm{O}_{3}, \mathrm{CH}_{2} \mathrm{Cl}_{2},-78^{\circ} \mathrm{C}$; (ii) $\mathrm{Me}_{2} \mathrm{~S}$; (b) transketolase, lithium hydroxypyruvate, thiamine pyrophosphate, $\mathrm{MgCl}_{2}$, tris buffer, $\mathrm{pH} 7.5$.

tors (thiamine pyrophosphate and magnesium chloride) in the tris buffer provided 4-keto-D-arabinose dimethyl acetal $8 .^{25}$ This compound may be used as a key intermediate in the synthesis of diverse pentoses.

\section{Experimental}

\subsection{General}

NMR spectra were recorded on Varian Inova AS400 spectrometer $(400 \mathrm{MHz})$. Infrared spectra were recorded on a Bomem MB-100 spectrometer. Optical rotations were measured using a JASCO DIP-360 digital polarimeter ( $c$ as gram of compound per $100 \mathrm{~mL}$ ). Flash column chromatography was carried out using 40 $63 \mu \mathrm{m}(230-400 \mathrm{mesh})$ silica gel. The enantiomeric excesses (ee) were determined by GC analysis on a Chiraldex G-TA ( $\gamma$-cyclodextrin trifluoroacetyl) capillary column $(20 \mathrm{~m} \times 0.25 \mathrm{~mm}$, film thickness $0.125 \mu \mathrm{m})$ using racemic compounds as references. $C$. antarctica lipase B (Chirazyme L-2) was obtained from Boehringer Mannheim. PSL (Pseudomonas sp. Lipase), CE (Cholesterol esterase), and PLE (Porcine liver esterase) were 
from Sigma, and PFL (P. fluorescens) was from Fluka. PCL ( $P$. cepacia lipase) and LPL (lipoprotein lipase 200S) were a gift from Amano. Transketolase was produced and purified as previously described. ${ }^{26}$

\subsection{1,1-Dimethoxybut-3-en-2-ol 2}

To a solution of vinylmagnesium bromide $(0.1 \mathrm{~mol})$ in THF (freshly prepared from magnesium and a commercial $5 \mathrm{M}$ solution of vinyl bromide in THF) cooled to $0{ }^{\circ} \mathrm{C}$ under dry atmosphere was added dropwise a solution of dimethoxy acetaldehyde in tert-butylmethyl ether $(45 \%, 26 \mathrm{~mL}, 0.1 \mathrm{~mol})$. The mixture was stirred at room temperature for $12 \mathrm{~h}$ and then the reaction quenched by the addition of a satd aq $\mathrm{NH}_{4} \mathrm{Cl}$ solution. The aqueous phase was extracted with ethyl acetate and the combined organic phases washed with brine, dried over $\mathrm{MgSO}_{4}$, and evaporated. The crude product was purified by flash chromatography (cyclohexane/EtOAc, 75:25) to give a colorless oil $(7.1 \mathrm{~g}, 55 \%):{ }^{1} \mathrm{H}$ NMR $\left(400 \mathrm{MHz}, \mathrm{CDCl}_{3}\right)$ $\delta 2.51(\mathrm{br} \mathrm{s}, 1 \mathrm{H}), 3.37(\mathrm{~s}, 3 \mathrm{H}), 3.40(\mathrm{~s}, 3 \mathrm{H}), 4.08(\mathrm{~m}$, $1 \mathrm{H}), 4.13(\mathrm{~d}, J=5.0 \mathrm{~Hz}, 1 \mathrm{H}), 5.20(\mathrm{~d}, J=10.0 \mathrm{~Hz}$, $1 \mathrm{H}), 5.37(\mathrm{~d}, J=17.0 \mathrm{~Hz}, 1 \mathrm{H}), 5.86(\mathrm{dd}, J=17.0$ and $10.0 \mathrm{~Hz}, 1 \mathrm{H}) ;{ }^{13} \mathrm{C}$ NMR $\left(100 \mathrm{MHz}, \mathrm{CDCl}_{3}\right) \delta 54.5$, 54.9, 72.1, 106.5, 116.7, 135.5; HRMS (CI, $\left.\mathrm{NH}_{3}\right)$ calcd for $\mathrm{C}_{6} \mathrm{H}_{12} \mathrm{O}_{3}\left(\mathrm{M}+\mathrm{NH}_{4}\right)^{+}: 150.1130$. Found: 150.1126 .

\subsection{1,1-Dimethoxypent-4-en-2-ol 3}

To a stirred solution of allylmagnesium bromide in dry THF $(1 \mathrm{M}, 10 \mathrm{~mL}, 10 \mathrm{mmol})$ at $0{ }^{\circ} \mathrm{C}$ was added dropwise a solution of dimethoxy acetaldehyde in tertbutylmethyl ether $(45 \%, 2.9 \mathrm{~mL}, 11 \mathrm{mmol}, 1.1$ equiv). The solution was stirred at $\mathrm{rt}$ for $12 \mathrm{~h}$ under a dry atmosphere. The reaction was quenched by the addition of a satd aq $\mathrm{NH}_{4} \mathrm{Cl}$ solution. The organic layer was decanted off and the aqueous layer extracted with ethyl acetate. The combined organic layers were washed with brine, dried over $\mathrm{MgSO}_{4}$, and concentrated. The crude product was purified by flash chromatography (cyclohexane/ EtOAc, $75: 25)$ to give a colorless oil $(910 \mathrm{mg}, 62 \%)$ : ${ }^{1} \mathrm{H}$ NMR $\left(400 \mathrm{MHz}, \mathrm{CDCl}_{3}\right) \delta 2.05$ (br s, $\left.1 \mathrm{H}\right), 2.20$ $(\mathrm{m}, 1 \mathrm{H}), 2.37(\mathrm{~m}, 1 \mathrm{H}), 3.41(\mathrm{~s}, 3 \mathrm{H}), 3.43(\mathrm{~s}, 3 \mathrm{H}), 3.65$ $(\mathrm{m}, 1 \mathrm{H}), 4.15(\mathrm{~d}, J=6.0 \mathrm{~Hz}, 1 \mathrm{H}), 5.07(\mathrm{~d}, J=15.0 \mathrm{~Hz}$, $1 \mathrm{H}), 5.12(\mathrm{~d}, J=8.0 \mathrm{~Hz}, 1 \mathrm{H}), 5.86(\mathrm{~m}, 1 \mathrm{H}) ;{ }^{13} \mathrm{C}$ NMR $\left(100 \mathrm{MHz}, \mathrm{CDCl}_{3}\right) \delta 36.2,54.7,54.9,70.4,106.2$, 117.1, 134.5; HRMS (CI, $\left.\mathrm{NH}_{3}\right)$ calcd for $\mathrm{C}_{7} \mathrm{H}_{14} \mathrm{O}_{3}$ $\left(\mathrm{M}+\mathrm{NH}_{4}\right)^{+}:$164.1287. Found: 164.1293.

\subsection{Preparation of diacetates 4 and 5: general procedure}

To a stirred solution of alcohol 2 or $3(12.1 \mathrm{mmol})$ in pyridine $(10 \mathrm{~mL})$ were added acetic anhydride ( 3 equiv) and a catalytic amount of DMAP, after which the solution was stirred overnight at rt under a dry atmosphere. The solution was diluted with ether, washed with brine, dried over $\mathrm{MgSO}_{4}$, and evaporated. The crude product was purified by flash chromatography (hexanes/EtOAc, 9:1) to give acetates 4 or 5 as colorless oils ( $75-80 \%)$.

3.4.1. 1-(Dimethoxymethyl)prop-2-enyl acetate $4 .{ }^{1} \mathrm{H}$ NMR $\left(400 \mathrm{MHz}, \mathrm{CDCl}_{3}\right) \delta 2.08(\mathrm{~s}, 1 \mathrm{H}), 3.37(\mathrm{~s}, 3 \mathrm{H})$, $3.38(\mathrm{~s}, 3 \mathrm{H}), 4.28(\mathrm{~d}, J=5.0 \mathrm{~Hz}, 1 \mathrm{H}), 5.24$ (d,
$J=10.0 \mathrm{~Hz}, 1 \mathrm{H}), 5.29(\mathrm{~d}, J=17.0 \mathrm{~Hz}, 1 \mathrm{H}), 5.31(\mathrm{~m}$, $1 \mathrm{H}), 5.84(\mathrm{~m}, 1 \mathrm{H}) ;{ }^{13} \mathrm{C}$ NMR $\left(100 \mathrm{MHz}, \mathrm{CDCl}_{3}\right) \delta$ 20.8, 54.3, 55.2, 72.8, 104.2, 118.2, 131.9, 169.6; HRMS $\left(\mathrm{CI}, \mathrm{NH}_{3}\right)$ calcd for $\mathrm{C}_{8} \mathrm{H}_{14} \mathrm{O}_{4}\left(\mathrm{M}+\mathrm{NH}_{4}\right)^{+}: 192.1236$. Found: 192.1227.

3.4.2. 1-(Dimethoxymethyl)but-3-enyl acetate $5 .{ }^{1} \mathrm{H}$ NMR $\left(400 \mathrm{MHz}, \mathrm{CDCl}_{3}\right) \delta 1.98(\mathrm{~s}, 3 \mathrm{H}), 2.22(\mathrm{~m}, 1 \mathrm{H})$, $2.37(\mathrm{~m}, 1 \mathrm{H}), 3.30(\mathrm{~s}, 3 \mathrm{H}), 3.32(\mathrm{~s}, 3 \mathrm{H}), 4.21(\mathrm{~d}$, $J=5.0 \mathrm{~Hz}, 1 \mathrm{H}), 4.97(\mathrm{~m}, 3 \mathrm{H}), 5.66(\mathrm{~m}, 1 \mathrm{H}) ;{ }^{13} \mathrm{C}$ NMR $\left(100 \mathrm{MHz} \mathrm{CDCl}_{3}\right) \delta 20.7,33.8,54.0,55.0,71.2,103.8$, $117.5,132.3,169.9$; HRMS (CI, $\left.\mathrm{NH}_{3}\right)$ calcd for $\mathrm{C}_{9} \mathrm{H}_{16} \mathrm{O}_{4}\left(\mathrm{M}+\mathrm{NH}_{4}\right)^{+}:$206.1392. Found: 206.1398 .

\subsection{Enzymatic acylation of alcohol 2}

To a solution of alcohol $2(1.38 \mathrm{~g}, 10.4 \mathrm{mmol})$ in vinyl acetate $(35 \mathrm{~mL})$ was added $C$. antarctica lipase $(1.40 \mathrm{~g})$ and the mixture stirred at rt. The reaction course was monitored by chiral GC and when the conversion reached $50 \%(36 \mathrm{~h})$, the reaction was quenched by filtration of the enzyme and the solvent evaporated. Chromatography of the residue with EtOAc/petroleum ether $(10: 90)$ afforded $(S)-2(457 \mathrm{mg}, 33 \%$, ee $=93 \%)$ and (R)-4 (782 mg, 43\%, ee $=95 \%)$.

\subsection{Enzymatic acylation of alcohol 3}

To a solution of alcohol 3 (937 mg, $6.4 \mathrm{mmol})$ in vinyl acetate $(25 \mathrm{~mL})$ was added $P$. fluorescens lipase $(1.00 \mathrm{~g})$ and the mixture was stirred at $\mathrm{rt}$. The reaction course was monitored by chiral GC and when the conversion reached $50 \%(24 \mathrm{~h})$, the reaction was quenched by filtration of the enzyme and the solvent evaporated. Chromatography of the residue with EtOAc/petroleum ether (10:90) provided alcohol $(S)-3 \quad(349 \mathrm{mg}, 37 \%$, ee $=92 \%)$ and acetate $(R)-5(526 \mathrm{mg}, 44 \%$, ee $=94 \%)$.

\subsection{Enzymatic hydrolysis of acetate 4}

Ester 4 (459 mg, $2.64 \mathrm{mmol}$ ) was suspended in a buffered aqueous solution $(20 \mathrm{~mL}$, phosphate $\mathrm{pH} 7.0)$. C. antarctica lipase $(450 \mathrm{mg})$ was added and the $\mathrm{pH}$ maintained at its initial value by the addition of $0.1 \mathrm{M}$ aqueous $\mathrm{NaOH}$. The reaction was monitored by chiral GC and stopped at the $50 \%$-of-hydrolysis point. The aqueous mixture was extracted with EtOAc and the organic layer dried over $\mathrm{MgSO}_{4}$ and concentrated. Chromatography of the residue with EtOAc/petroleum ether (10:90) gave alcohol $(R)-2(94 \mathrm{mg}, 27 \%$, ee $=92 \%)$ and acetate $(S)-4$ $(165 \mathrm{mg}, 36 \%$, ee $=94 \%)$.

\subsection{Enzymatic hydrolysis of acetate 5}

Ester 3 (524 mg, $2.79 \mathrm{mmol}$ ) was suspended in a buffered aqueous solution $(10 \mathrm{~mL}$, phosphate $\mathrm{pH} 7.0)$. Lipoprotein lipase LPL 200S (500 mg) was added and the $\mathrm{pH}$ maintained at its initial value by the addition of $0.1 \mathrm{M}$ aqueous $\mathrm{NaOH}$. The reaction was monitored by chiral GC and stopped at the $50 \%$-of-hydrolysis point. The aqueous mixture was extracted with EtOAc and the organic layer dried over $\mathrm{MgSO}_{4}$ and concentrated. Chromatography of the residue with EtOAc/petroleum 
ether (10:90) gave alcohol (R)-3 (123 mg, 30\%, ee $=98 \%)$ and acetate $(S)-5(214 \mathrm{mg}, 41 \%$, ee $=96 \%)$.

\subsection{Determination of absolute configurations by chemical correlation: general procedure}

A solution of 2 or 3 ( $2 \mathrm{mmol}$, from enzymatic acylation) and $\mathrm{LiBF}_{4}(2 \mathrm{mmol})$ in $\mathrm{CH}_{3} \mathrm{CN} / \mathrm{H}_{2} \mathrm{O}(95: 5,3.6 \mathrm{~mL})$ was stirred at $\mathrm{rt}$ for 5 days. The solvent was evaporated and the residue dissolved in water $(10 \mathrm{~mL}) . \mathrm{NaBH}_{4}(2 \mathrm{mmol})$ was added and the reaction mixture stirred at $\mathrm{rt}$ for $1 \mathrm{~h}$. The reaction mixture was extracted with EtOAc (continuous extractor). The organic phase was dried over $\mathrm{MgSO}_{4}$ and concentrated. The crude product was purified by flash chromatography (EtOAc/cyclohexane, $70: 30$ ) to give 6 or 7 as colorless oils. Analytical data were in agreement with the published values for but-3ene-1,2-diol $6^{27}$ and pent-4-ene-1,2-diol 7. ${ }^{28}$

\subsection{0. $(3 S, 4 S)-1,3,4$-Trihydroxy-5,5'-dimethoxypentanone 8}

Ozone was passed through a solution of alcohol 2 (407 mg, $3.1 \mathrm{mmol}$ ) in $\mathrm{CH}_{2} \mathrm{Cl}_{2}$ at $-78^{\circ} \mathrm{C}$ until a blue color persisted. The excess ozone was purged with argon, $\mathrm{Me}_{2} \mathrm{~S}(260 \mu \mathrm{L}, 3.6 \mathrm{mmol})$ was added, and the mixture stirred at $-78{ }^{\circ} \mathrm{C}$ for $1 \mathrm{~h}$ and then at rt overnight. The solvent was evaporated. To a solution of the crude aldehyde in tris buffer $(15.4 \mathrm{~mL})$ were added thiamine pyrophosphate (14.2 $\mathrm{mg}, 0.031 \mathrm{mmol}), \mathrm{MgCl}_{2}$ (4.4 $\mathrm{mg}, 0.046 \mathrm{mmol}$ ), and lithium hydroxypyruvate (396 mg, $3.6 \mathrm{mmol}$ ). The mixture was adjusted to $\mathrm{pH} 7.5$ by the addition of aq $\mathrm{NaOH}$ and the reaction initiated by the addition of transketolase $(100 \mathrm{U})$. The solution was stirred at $\mathrm{rt}$ for $24 \mathrm{~h}$ and then quenched by addition of $\mathrm{MeOH}(40 \mathrm{~mL})$. The mixture was stirred for $1 \mathrm{~h}$, the solids collected by centrifugation, and the solvents evaporated. The crude product was purified by flash chromatography $\left(\mathrm{CH}_{2} \mathrm{Cl}_{2} / \mathrm{MeOH}, 90: 10\right)$ to give 8 as a colorless oil $(223 \mathrm{mg}, 37 \%):[\alpha]_{\mathrm{D}}^{23}=-20.5(c 0.98$, $\mathrm{MeOH}) ;{ }^{1} \mathrm{H}$ NMR (400 MHz, CD $\left.{ }_{3} \mathrm{OD}\right) \delta 3.43$ (s, 1H), $3.44(\mathrm{~s}, 1 \mathrm{H}), 3.89(\mathrm{dd}, J=7.3$ and $2.0 \mathrm{~Hz}, 1 \mathrm{H}), 4.34(\mathrm{~d}$, $J=2.0 \mathrm{~Hz}, 1 \mathrm{H}), 4.43(\mathrm{~d}, J=7.3 \mathrm{~Hz}, 1 \mathrm{H}), 4.45(\mathrm{~d}$, $J=19.3 \mathrm{~Hz}, 1 \mathrm{H}), 4.53(\mathrm{~d}, J=19.3 \mathrm{~Hz}, 1 \mathrm{H}) ;{ }^{13} \mathrm{C}$ NMR $\left(100 \mathrm{MHz}, \mathrm{CD}_{3} \mathrm{OD}\right) \delta 54.7,55.8,67.8,73.0,77.0$, $105.5,213.5$; HRMS (EI) calcd for $\mathrm{C}_{7} \mathrm{H}_{14} \mathrm{O}_{6}$ $\left(\mathrm{M}-\mathrm{CH}_{5} \mathrm{O}_{2}\right)^{+}:$145.0501. Found: 145.0500 .

\section{Acknowledgments}

The authors would like to thank the Natural Sciences and Engineering Research Council of Canada (NSERC) for financial support.

\section{References}

1. Heathcock, C. H. In Comprehensive Organic Synthesis; Trost, B. M., Fleming, I., Heathcock, C. H., Eds.; Pergamon: Oxford, 1991; Vol. 2.

2. Polomo, C.; Oiarbide, M.; Garcia, J. M. Chem. Soc. Rev. 2004, 33, 65 .
3. Arya, P.; Qin, H. Tetrahedron 2000, 56, 917.

4. Denmark, S. E.; Stavenger, R. A. Acc. Chem. Res. 2000, 33, 432 .

5. Machajewski, T. D.; Wong, C. H. Angew. Chem., Int. Ed. 2000, 39, 1352.

6. (a) Hecquet, L.; Demuynck, C.; Schneider, G.; Bolte, J. J. Mol. Catal. B: Enzym. 2001, 11, 771; (b) Turner, N. J. Curr. Opin. Biotechnol. 2000, 11, 527.

7. Silvestri, M. G.; Desantis, G.; Mitchell, M.; Wong, C. H. Top. Stereochem. 2003, 23, 267.

8. (a) Breuer, M.; Hauer, B. Curr. Opin. Biotechnol. 2003, 14, 570; (b) Fessner, W. D.; Helaine, V. Curr. Opin. Biotechnol. 2001, 12, 574 .

9. List, B.; Shabat, D.; Zhong, G.; Turner, J. M.; Li, A.; Bui, T.; Anderson, J.; Lerner, R. A.; Barbas, C. F. J. Am. Chem. Soc. 1999, 121, 7283.

10. Northrup, A. B.; Macmillan, D. W. C. J. Am. Chem. Soc. 2002, 124, 6798 .

11. Jarvo, E. R.; Miller, S. J. Tetrahedron 2002, 58, 2481.

12. List, B. Tetrahedron 2002, 58, 5573.

13. For a recent exemple related to the title compounds, see: Radha Krishna, P.; Kannan, V.; Sharma, G. V. M. J. Org. Chem. 2004, 69, 6467.

14. For asymmetric syntheses of related acids, esters or diols, see: (a) Dallanoce, C.; De Amici, M.; Carrea, G.; Secundo, F.; Castellano, S.; De Micheli, C. Tetrahedron: Asymmetry 2000, 11, 2741; (b) Wang, D.; Wang, Z. G.; Wang, M. W.; Chen, Y. J.; Liu, L.; Zhu, Y. Tetrahedron: Asymmetry 1999, 10, 327; (c) Czapla, A.; Chajewski, A.; Kiegiel, K.; Bauer, T.; Wielogorski, Z.; Urbanczyk-Lipkowska, Z.; Jurczak, J. Tetrahedron: Asymmetry 1999, 10, 2101; (d) Macritchie, J. A.; Silcock, A.; Willis, C. L. Tetrahedron: Asymmetry 1997, 8, 3895; (e) Pearson, W. H.; Cheng, M. C. J. Org. Chem. 1986, 51, 3746; (f) Wong, C. H.; Matos, J. R. J. Org. Chem. 1985, 50, 1992.

15. Makin, S. M.; Telegina, N. I. I. Gen. Chem. USSR 1962, 32,1082 .

16. For related syntheses, see: (a) Kobori, Y.; Myles, D. C.; Whitesides, G. M. J. Org. Chem. 1992, 57, 5899; (b) Parrain, J. L.; Beaudet, I.; Cintrat, J. C.; Duchêne, A.; Quintard, J. P. Bull. Soc. Chim. Fr. 1994, 131, 304; (c) Stamboli, A.; Amouroux, R.; Chastrette, M.; Mattioda, G.; Blanc, A. J. Organomet. Chem. 1986, 307, 139; (d) Liu, K. C.; Pederson, R. L.; Wong, C. H. J. Chem. Soc., Perkin Trans. 1 1991, 2669; (e) Fessner, W. D.; Goße, C.; Jaeschke, G.; Eyrish, O. Eur. J. Org. Chem. 2000, 125.

17. A lipase-catalyzed acylation of 3 was reported but ee of the remaining substrate and absolute configurations were not determined: Kim, M. J.; Lim, I. T.; Choi, G. B.; Whang, S. Y.; Ku, B. C.; Choi, J. Y. Bioorg. Med. Chem. Lett. 1996, 6, 71 .

18. Lipshutz, B. H.; Harvey, D. F. Synth. Commun. 1982, 12, 267.

19. Kazlauskas, R. J.; Weissfloch, A. N. E.; Rappaport, A. T.; Cuccia, L. A. J. Org. Chem. 1991, 56, 2656.

20. Burgess, K.; Jennings, L. D. J. Am. Chem. Soc. 1991, 113, 6129.

21. Seco, J. M.; Quiñoá, E.; Riguera, R. Chem. Rev. 2004, 104, 17.

22. Seco, J. M.; Quiñoá, E.; Riguera, R. Tetrahedron: Asymmetry 2001, 12, 2915.

23. Dale, J. A.; Mosher, H. S. J. Am. Chem. Soc. 1973, 95, 512.

24. Crestia, D.; Demuynck, C.; Bolte, J. Tetrahedron 2004, 60, 2417.

25. Williams, D. T.; Jones, J. K. N.; Dennis, N. J.; Ferrier, R. J.; Overend, W. G. Can. J. Chem. 1965, 43, 955.

26. Hecquet, L.; Demuynck, C.; Bolte, J. J. Mol. Catal. B: Enzym. 2001, 6, 797. 
27. (a) Schaus, S. E.; Brandes, B. D.; Larrow, J. F.; Tokunaga, M.; Hansen, K. B.; Gould, A. E.; Furrow, M. E.; Jacobsen, E. N. J. Am. Chem. Soc. 2002, 124, 1307; (b) Botes, A. L.; Weijers, C. A. G. M.; Botes, P. J.; van Dyk, M. S. Tetrahedron: Asymmetry 1999, 10, 3327; (c) Bergmeir, S. C.; Stanchina, D. M. J. Org. Chem. 1999, 64,
2852; (d) Crawford, R. J.; Lutener, S. B.; Cockcroft, R. D. Can. J. Chem. 1976, 55, 3364.

28. (a) Enders, D.; Lenzen, A.; Müller, M. Synthesis 2004, 1486; (b) Jana, G.; Viso, A.; Diaz, Y.; Castillón, S. Eur. J. Org. Chem. 2003, 209; (c) Diaz, Y.; Bravo, F.; Castillón, S. J. Org. Chem. 1999, 64, 6508. 